\title{
Testicular Seminoma with Syncytiotrophoblastic Cells
}

National Cancer Institute

\section{Source}

National Cancer Institute. Testicular Seminoma with Syncytiotrophoblastic Cells. NCI

Thesaurus. Code C39919.

A testicular seminoma characterized by the presence of syncytiotrophoblastic giant cells. 